\title{
EDITORIAL
}

\section{El olivo (Olea europaea L) en América}

\author{
The olive (Olea Europaea L) in America
}

Eugenio Manuel Sotomayor León

Dr. Ingeniero Agrónomo

Facultad de Ciencias Agronómicas

Universidad de Tarapacá

Arica, Chile

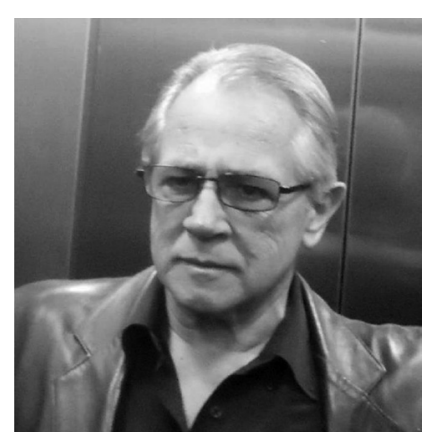

Eugenio Manuel Sotomayor León Faculty of Agricultural Sciences University of Tarapaca Arica, Chile
El olivo fue una de las primeras plantas introducidas desde España a Las Antillas, a través de zuecas. Sin embargo, no logró aclimatarse al ambiente tropical. Posteriormente, Fray Martín logró propagar este árbol en México, al introducir exitosamente olivos provenientes de Valencia al puerto de Veracruz. Hacia mediados del S. XVII, el olivo había alcanzado su máximo desarrollo en México cuya población había aumentado gracias a disposiciones obligatorias para quienes se aventuraban al continente americano desde España como "que nadie saliera con rumbo de nuevo mundo sin cargar y condicionar algún material vegetal del árbol productos del oro verde". Algunos de estos ejemplares aún existen en Tuyehuasco. Los jesuitas españoles propagaron el olivo mediante estacas y semillas en América del Norte entre finales del S. XVII e inicios del S. XVIII en las misiones mexicanas. En 1769, el padre franciscano Fray Junípero Serra, fundó la primera misión californiana en San Diego de Alcalá y lograron fundar veintiún misiones hasta Sonoma. Estas misiones producían aceite de muy buena calidad y la variedad resultante se denominó "Mission".
The olive was one of the first plants to be introduced from Spain to the Antilles, by means of "zuecas". However, they did not adjust to the tropical climate. Later, Fray Martín managed to propagate this tree in Mexico; he successfully introduced olives from Valencia to the port of Veracruz. By the middle of the $17^{\text {th }}$ century the olive had reached its maximum development; its numbers increased due to obligatory regulations for those who came to the American continents from Spain such as "let no one sail to the New World without preparing and taking some tree material products of green gold". Some of these trees still exist in Tuyehuasco. The Spanish Jesuits propagated olives using cuttings and seeds in North America between the end of the $17^{\text {th }}$ century and the beginning of the $18^{\text {th }}$ in Mexican missions. In 1769 the Franciscan priest Fray Junipero Serra founded the first California mission in San Diego de Alcalá, and eventually founded 21 missions, as far north as Sonoma. These missions produced very good quality oil; the variety came to be called Mission.

Many years before, in 1560 according to the royal commentaries on the Incas of the half-breed 
Muchos antes, en 1560, según los comentarios reales de los Incas del cronista mestizo Inca don Garcilaso de la Vega, se introdujo exitosamente el cultivo del olivo en el Perú y luego en Chile, con data cronológica de 30 años después del inicio de la Conquista del Imperio de los Incas o Tawantinsuyo. El olivo llegó al Perú de la mano del acaudalado Don Antonio de Ribera, quien se embarca en Sevilla en 1559, trayendo como preciada carga varias estacas de olivos seleccionados. De las cien estacas que trajo para reproducción solamente tres llegaron en condiciones de enraizar. Éstas fueron plantadas en un área especial de su huerta, celosamente cuidadas por esclavos negros y perros guardianes. La historia relata que un día, don Antonio fue, como de costumbre, a pasear muy temprano por su huerto y se encontró con que una de sus preciadas estacas de verde olivo, había desaparecido. Sobre este hurto, existen hasta tres versiones del latrocinio. La primera dice que fue a parar a Arequipa, específicamente al valle de Camaná. Otra, que llegó más al sur y se sembró en el valle de Azapa y, la tercera teoría dice que originó los olivares de Valparaíso, en Chile. Esta última versión es avalada por el historiador don Ricardo Palma, quien cuenta que por intermedio de un secreto de confesión, un acaudalado agricultor chileno pidió perdón divino por su mala acción y como penitencia recibió la tarea de regresar la estaca, por supuesto, en forma simbólica y anónima.

Las primeras plantaciones de olivos se hicieron en Lima en el año 1560, por don Antonio de Rivera desde Sevilla. Luego fueron plantadas en un huerto en Rimac (hoy Convento de los Descalzos) por don Gonzalo Guillen. Posteriormente fue propagado en los valles de Casma y Huarmey. Asimismo, se introdujo a los valles del Sur como Acarí, Yauca, Camaná, Ilo y el valle de Azapa. En el año 1753, se tiene referencia del cultivo del olivo en el Departamento de Tacna, el huerto de Santa Rosa de Para, la propagación fue en los Palos o cercados de la ciudad de Tacna. En Chile, los primeros olivos que se plantaron fue en la zona del Pacífico. Se distribuyó en el país por territorios, por la región del Norte hasta Coquimbo, en historian don Garcilaso de la Vega, the olive was successfully introduced into Peru and then in Chile, 30 years after the beginning of the conquest of the Inca empire or Tawantinsuyo. The olive reached Peru due to the rich don Antonio de Ribera, who left Sevilla in 1559 bringing cuttings of selected olives as precious baggage. Only three of the 100 cuttings he brought arrived in conditions to be rooted. These were planted in a special part of his orchard, jealously guarded by black slaves and guard dogs. History relates that one day don Antonio as usual walked through his orchard early one morning, and found that one of his precious olive cuttings had disappeared. There are three versions of the result of this larceny; the first is that it wound up in Arequipa, specifically in Canamá Valley; the second that it went farther south and was planted in the Azapa Valley of extreme northern Chile; the third version is that it originated the olive orchards of Valparaiso, Chile. The last version is supported by the historian don Ricardo Palma, who relates that in a secret confession a rich Chilean farmer asked for divine pardon for his bad action and received as penitence the task of returning the cutting, of course symbolically and anonymously.

The first olive plantations were planted in Lima in 1560 by Don Antonio de Rivera. Then they were planted in an orchard in Rimac (today the Convento de los Descalzos) by Gonzalo Guillen. Later they were propagated in the Casma and Huarmey Valleys, as well as southern valleys such as Acari, Yauca, Camaná, Ilo and Azapa. There is a reference to olive cultivation in 1753 in the Departamento de Tacna in the orchard of Santa Rosa de Para; they were propagated in Los Palos or near the city of Tacna. The first olives were planted in Chile in the zone of the Pacific. They were distributed in the country by territories; in the northern region to Coquimbo, in the central zone from Aconcagua to Maule and in the south from Nuble to La Araucanía. Thus the varieties introduced from Spain adapted to the different microclimates present along the length and width of the country. 
la zona Central desde Aconcagua hasta Maule y hacia el sur, de Ñuble hasta La Araucanía. De esta manera, las variedades introducidas desde España se adaptaron a diferentes microclimas presentes a lo largo y ancho del país.

La introducción del olivo en Argentina no está bien dilucidada, una de las teorías habla de la llegada a través de una expedición militar desde Chile al mando del Capitán Diego de Alvarado, siendo diseminada por todo el Norte del territorio adaptándose perfectamente en diversos lugares y en especial en Arauco (La Rioja). Testimonio de esa introducción lo constituye el resto de una antiquísima plantación, donde se encuentra el denominado "Olivo de las Ánimas", existente en Aimogasta, es llamado así debido a que sus frutos se destinaron durante muchos años a ritos litúrgicos. En La Rioja, aun se conserva el "Olivo Histórico" de más de 450 años de edad de variedad Arauco, único ejemplar que se salvó de la tala ordenada por el Rey de España durante el S. XVIII. En Uruguay, los inicios del cultivo se remontan a los años 1780, donde se introdujeron 250 plantas de olivo desde Buenos Aires. En 1934 hasta 1950 se plantaron 1.000 hás, cuyas variedades llegaron de España e Italia. En Colombia se plantaron en la región del Alto Ricaurte-Boyacá-Colombia hace más de 200 años. Actualmente, existen alrededor de 18.000 árboles de los cuales, aproximadamente, tres mil son plantaciones nuevas sembradas durante los últimos cuatro años. En Bolivia durante la Colonia en Cochabamba, ya se había plantado algunos ejemplares, prueba de ellos es la existencia que se conservan hasta la actualidad. La mayoría de las variedades de olivo que existen en el país, son de origen de la Cuenca del Mediterráneo y fueron introducidos desde la Argentina la variedad "Arauco" y desde Chile, la variedad "Azapa". La provincia que presenta mayor potencial productivo para la producción de olivos es Mizque.

Más reciente, en Brasil, a partir de 1948, se inician algunas plantaciones de carácter experimental. Estos primeros núcleos olivícolas se han desarrollado en los estados de Río Grande y San Pablo. Por sus condiciones ambientales, no es
The introduction of the olive in Argentina is not well known; one of the theories speaks of its arrival in a military expedition from Chile under Capitan Diego de Alvarado; in any event it was disseminated in all the northern area of the country, and adapted perfectly well in a number of places, especially in Arauco (La Roja). There are remains of an ancient plantation where the Olivo de las Ánimas (olive of the souls) still exists in Aimogasta; it received this name because for many years its fruits were used for liturgical rites. The Olivo Historico (historical olive) of the Arauco variety is still alive in La Rioja after more than 450 years; it was the only tree that survived the felling of all olives ordered by the king of Spain during the $18^{\text {th }}$ century.

The first olives in Uruguay were planted in the 1780s; 250 olive plants were introduced from Buenos Aires. Between 1934 and 19501000 hectares were planted with varieties from Spain and Italy. Olives were planted in Colombia in the region of Alto Ricaurte-Boyacá over 200 years ago. There are currently around 18,000 trees, 3000 of which are new plantations planted in the last four years. In Bolivia the first olives were planted during Colonial times in Cochabamba, some of which are still living. Most of the olive varieties in the country are from the Mediterranean Basin, although the Arauco variety was introduced from Argentina and the Azapa variety from Chile. Mizque is the province with greatest productive potential for olive production.

The first experimental plantations were planted in Brazil only in 1948; these first olive nuclei have developed in the states of Rio Grande and San Pablo. Because of the environmental conditions, yields similar to other South American countries which have regions with optimum aptitude for olive cannot be expected. Venezuela began experimenting with olive production in 2010, evaluating ten varieties from Syria. The five states where the trial is being held are Lara, Trujillo, Mérida, Falcón and Aragua, due to their climatic conditions and specifically for the cold hours necessary to complete the fruit cycle. 
posible esperar rendimientos similares a los de otros países americanos que poseen regiones de aptitudes óptimas para el cultivo del olivo. En 2010, Venezuela incursiona en la producción de olivo, como una alternativa estratégica de evaluar diez variedades procedente de la República de Siria. Se han elegido cinco estados: Lara, Trujillo, Mérida, Falcón y Aragua por la condiciones agroclimáticas y específicamente por las horas frío, para culminar su proceso productivo.

Se concluye que el olivo traído por los conquistadores se adaptó bien en América. Hoy en día la mayoría de los países han aumentado su superficie y producción gracias a las nuevas tecnologías en las labores culturales y manejo agronómico.
We conclude that the olive brought by the conquistadores adapted well in America. Today most of the countries have increased the area planted and production, thanks to the new technologies in the cultural labors and agricultural management. 